\title{
Anticancer activities of toxic isolate of Xestospongia testudinaria sponge
}

\author{
Made Dira Swantara ${ }^{1}$, Wiwik Susanah Rita ${ }^{2}$, Nyoman Suartha ${ }^{3}$ and Kadek Karang Agustina ${ }^{4}$
}

1. Department of Applied Chemistry, Graduate School, Udayana University, Denpasar, Indonesia; 2. Department of Chemistry, Udayana University, Badung, Indonesia; 3. Department of Internal Medicine, Faculty of Veterinary Medicine, Udayana University, Denpasar, Indonesia; 4. Department of Public Health, Faculty of Veterinary Medicine, Udayana University, Denpasar, Indonesia.

Corresponding author: Made Dira Swantara, e-mail: dira_swantara@unud.ac.id

Co-authors: WSR: susunah_rita@unud.ac.id, NS: nyoman_suartha@unud.ac.id, KKA: k.agustina@unud.ac.id Received: 12-04-2019, Accepted: 22-07-2019, Published online: 18-09-2019

doi: 10.14202/vetworld.2019.1434-1440 How to cite this article: Swantara MD, Rita WS, Suartha N, Agustina KK (2019) Anticancer activities of toxic isolate of Xestospongia testudinaria sponge, Veterinary World, 12(9): 1434-1440.

\begin{abstract}
Aim: The purposes of this study were to determine the anticancer activity of Xestospongia testudinaria sponge isolate and identify the responsible compounds.

Materials and Methods: The metabolites were extracted using methanol maceration at room temperature. The separation and purification of metabolites were performed using fractionation and column chromatography. The toxicity was examined using the brine shrimp lethality assay, and the toxic isolates were tested for anticancer activity against HeLa cells. Gas chromatography-mass spectrometry analysis was used to identify the compounds in the isolate.

Results: When the methanol extract was partitioned with n-hexane, chloroform, and n-butanol, the chloroform fraction was the most toxic, with a concentration that results in $50 \%$ lethality $\left(\mathrm{LC}_{50}\right)$ value of 39.81 ppm. After separation of the chloroform extract, fraction $\mathrm{B}(\mathrm{FB})$ was the most toxic, with an $\mathrm{LC}_{50}$ value of $44.67 \mathrm{ppm}$. The isolate from $\mathrm{FB}$ showed anticancer activity with a concentration at which $50 \%$ of growth was inhibited $\left(\mathrm{IC}_{50}\right)$ of $2.273 \mathrm{ppm}$. In total, 21 compounds were identified in anticancer isolates: Nonanedioic acid; tetradecanoic acid; trans-phytol; 2-pentadecanone6,10,14-trimethyl; pentadecanoic acid; 2-hexadecen-1-ol, 3,7,11,15-tetramethyl-; pentadecanoic acid; 2-hexadecen-1-ol, 3,7,11,15-tetramethyl-; 2,3,7-trimethyloctanal; palmitic acid; docosanoic acid, ethyl ester; 1,E-11,Z-13-octadecatriene; chloromethyl 4-chlorododecanoate; 1-tricosene; 9,12-octadecadienoic acid; 4,8,12,16-tetramethylheptadecan-4-olide; 1-docosene; heneicosane; phosphonic acid, dioctadecyl ester; dodecane,4,6-dimethyl-; n-tetratriacontane; 1-iodohexadecane; and n-heneicosane.
\end{abstract}

Conclusion: These findings indicate that the isolate of $X$. testudinaria can be used as a natural anticancer toward HeLa cell.

Keywords: anticancer activity, HeLa cell, Xestospongia testudinaria.

\section{Introduction}

Cancer is caused by the abnormal growth and development of cells in the body [1]. During the course of the disease, these cells may spread to other parts of the body, ultimately resulting in death where the currently available therapies are not effective [2-5]. Cancer is the second most common cause of death after heart disease, responsible for more than 500,000 deaths per year in the United States [6] and an estimated 100 new patients in every 100,000 inhabitants diagnosed every year in Indonesia [7]. Current cancer treatments generally combine surgical and radiation methods with chemotherapy [8], but the methods have not led to optimal results.

The development of new anticancer drugs has become a priority because of the high cost and

Copyright: Swantara, et al. Open Access. This article is distributed under the terms of the Creative Commons Attribution 4.0 International License (http://creativecommons.org/licenses/ by/4.0/), which permits unrestricted use, distribution, and reproduction in any medium, provided you give appropriate credit to the original author(s) and the source, provide a link to the Creative Commons license, and indicate if changes were made. The Creative Commons Public Domain Dedication waiver (http:// creativecommons.org/publicdomain/zero/1.0/) applies to the data made available in this article, unless otherwise stated. low selectivity of the currently available drugs [9]. A wide range of natural resources, including marine organisms, has been considered in the search for new anticancer compounds [10]. Some researchers believe that sponges are a potential source of bioactive compounds from the ocean. Nearly 5000 compounds have been isolated from these sponges and determined to have various biological effects such as antimicrobial, antifungal, antiviral, and anticancer activities [11]. Metabolite extracts from sea sponges contain bioactive compounds with antiviral [12], anti-HIV, anti-inflammatory, antifungal, antileukemia [13], enzyme inhibitory [14], antimalarial [15], antioxidant [16], cytoprotective, and antitumor [17] activity.

Few studies have assessed the anticancer activity of Xestospongia testudinaria sponge. The alcohol and n-hexane extracts (EH) from $X$. testudinaria from the Saudi Red Sea were found to have strong cytotoxic activity against human cervical cancer (HeLa), human hepatocellular carcinoma (HepG-2), and human medulloblastoma (Daoy) cell lines [18]. The methanol extract of $X$. testudinaria sponge from Sanur, Bali, Indonesia had anticancer activity against 
HeLa cells with an $\mathrm{IC}_{50}$ value of 1327 ppm [19]. The antitumor activity of two new polyacetylene sponges Xestospongia spp. from the Red Sea was also reported [20]. Moreover, effects other than anticancer of $X$. testudinaria sponge extract have been widely reported: $X$. testudinaria sponge showed antibacterial activity [20-22]; Vietnamese $X$. testudinaria sponge has antifouling activity of 26,27-cyclosterols [23]; the toxicity of the methanol extract of $X$. testudinaria sponge was reported to have a concentration that results in $50 \%$ lethality $\left(\mathrm{LC}_{50}\right)$ value of $31.62 \mathrm{ppm}[24,25]$. Five compounds identified in the sponges (sapinofuranone, xestospongic acid, 24-hydroperoxy-24-vinyl-cholesterol, saringosterol, and 29-hydroperoxystigmasta-5,24-dien-3 $\beta$-ol) were toxic to Artemia salina larvae with $\mathrm{LC}_{50}$ values between 0.56 and $6.99 \mu \mathrm{M}$ [24].

A preliminary test for anticancer activity was conducted using the brine shrimp lethality assay [26]. If material has an $\mathrm{LC}_{50}$ value of below $1000 \mathrm{ppm}$, this indicates anticancer potential and suggests the use of further anticancer testing in HeLa cells [19,27]. The methanol extract of $X$. testudinaria sponge from Sanur Bali had anticancer activity with a concentration at which $50 \%$ of growth was inhibited $\left(\mathrm{IC}_{50}\right)$ of $1327 \mathrm{ppm}$ [19].

The purposes of this study were to determine the anticancer activities of toxic isolates of $X$. testudinaria sponge from Sanur, Bali, Indonesia, and identify the responsible compounds.

\section{Materials and Methods \\ Ethical approval}

The study only used invertebrate, so ethical approval was not necessary.

\section{Materials}

The $X$. testudinaria sponge was collected from the coastal waters of Sanur, Bali, on May 9, 2018. Methanol, n-hexane, chloroform, and n-butanol were purchased from Merck, Germany. Brine shrimp Artemia salina eggs were purchased from American Technology. The cell line was purchased from the Primate Study Centre, Bogor Agriculture University. Gas chromatography-mass spectrometry (GC-MS) was performed using a GC-MS-QP2010 Ultra Shimadzu from Japan.

\section{Sample preparation and extraction}

Fresh sponge samples were washed with water until clean, cut into small pieces, and dried away from direct sunlight for 7 days. After drying, the sample was sieved through at 100 mesh filter to ensure appropriate homogeneity. In total, $500 \mathrm{~g}$ dry powder of sample was extracted using methanol maceration. Every $24 \mathrm{~h}$, the extract was filtered, and the pulp was re-extracted using fresh methanol. This extraction process was conducted 3 times. All the methanol extracts were evaporated using a rotary evaporator to yield the crude extract [19].

\section{Fractionation}

The crude extract (10 g) was completely dissolved in a methanol-water mixture (3:7), and then the methanol was removed by evaporation. The water extract was fractioned successively with $\mathrm{n}$-hexane $(3 \times 100 \mathrm{~mL})$, chloroform $(3 \times 100 \mathrm{~mL})$, and $\mathrm{n}$-butanol $(3 \times 100 \mathrm{~mL})$. The solvents were removed by evaporation to obtain the $\mathrm{EH}$, chloroform extract (EC), and n-butanol extract (EB). All three extracts (EH, EC, and EB) were tested for toxicity [19].

\section{Separation and purification}

The most toxic extracts were then separated by silica gel column chromatography using suitable eluents to obtain several fractions. All fractions were tested for toxicity. The most toxic fraction was tested for purity by thin-layer chromatography (TLC) using several eluent systems. If the isolate provided a single stain on the TLC plate in various eluent systems, then the isolate was considered pure according to TLC; finally, the anticancer effect of the isolate was determined in HeLa cells [19].

\section{Toxicity test}

The medium for larvae hatching was made by filtering seawater. Seawater was placed in an aquarium, which was divided into two parts; one was dark and the other was bright. A. salina eggs $(50 \mathrm{mg})$ were placed or immersed in the dark part and left for $48 \mathrm{~h}$ until it hatched into a mature larva and was ready to use for testing. Each methanol and n-EH (20 mg) were dissolved into $2 \mathrm{~mL}$ of solvent. These solutions were considered as $500 \mu \mathrm{L}, 50 \mu \mathrm{L}$, and $5 \mu \mathrm{L}$, respectively; each solution was inserted into the test tube, and the solvent was evaporated. Dimethyl sulfoxide (nearly $50 \mu \mathrm{L}$ ), seawater $(1 \mathrm{~mL})$, and 10 larvae were placed into a test tube containing the sample; the solvent was evaporated, and seawater was added to a volume of $5 \mathrm{~mL}$, to obtain extract concentrations of 1000,100 , and $10 \mathrm{ppm}$. A concentration of $0 \mathrm{ppm}$ (solution without the addition of the extract) was prepared as a control. After $24 \mathrm{~h}$, the death of A. saline larvae was measured. The standard assessment of larval mortality is when the larvae do not show movement during an observation period of several seconds [28]. The number of live and dead larvae was recorded, and the data were analyzed to find the $\mathrm{LC}_{50}$.

\section{Anticancer test}

The toxic isolate was assayed for its anticancer activity against HeLa cells [29]. HeLa cells were cultured in Roswell Park Memorial Institute 1640 medium, and the initial number of cells was counted using a microscope. The cells were trypsinized, harvested, and centrifuged to form two layers (sediment and supernatant). The supernatant was removed and the precipitate was pelletized; $1 \mathrm{~mL}$ of complete medium was added and then the number of cells as counted using a hemocytometer. Subsequently, $2 \times 10^{4}$ cells were seeded in $100 \mu \mathrm{L}$ 
of the medium in a 96-well plate and incubated for $1-2 \mathrm{~h}$ to allow the cells to adhere. Subsequently, $100 \mu \mathrm{L}$ extracts of the test material were added at various concentrations $(1000,500,250,125,62.5$, $31.25,15.62,7.81,3.91,1.95,0.97,0.48,0.24,0.12$, and $0.06 \mu \mathrm{g} / \mathrm{mL}$ ), to make a total volume of $200 \mu \mathrm{L}$ in each well. The cells were then incubated for $24 \mathrm{~h}$ at $37^{\circ} \mathrm{C}$. After $24 \mathrm{~h}$, the cells were observed using the microscope. 3-(4,5-Dimethylthiazole-2-yl)-2,5diphenyltetrazolium bromide (MTT; $5 \mu \mathrm{g} / \mathrm{mL}$ ) was added to each and incubated for $4 \mathrm{~h}$. Subsequently, stop solution of sodium dodecyl sulfate (SDS) $10 \%$ in $0.01 \mathrm{~N} \mathrm{HCl}$ was added into each well and incubated overnight. The absorbance at $500 \mathrm{~nm}$ was observed using an enzyme-linked immunosorbent assay plate reader.

\section{Identification of compounds}

Anticancer compounds were separated using GC-MS. The mass spectrum of the active isolates obtained was compared with standard reference spectra that were programmed on the device (GC-MS-QP2010 Ultra Shimadzu) [30,31].

\section{Anticancer activity}

Anticancer activity against HeLa cells was determined using the MTT assay. The MTT assay is a colorimetric method used to measure cell proliferation. The principle of the assay is the reduction of yellow tetrazolium salt MTT, which is reduced to purple formazan crystals by living mitochondria [32]: MTT is absorbed into live cells and reduced by succinate dehydrogenase in the electron transport chain of mitochondria to formazan. The formed formazan crystals are dissolved in $10 \%$ SDS, forming a purple solution. The MTT reduction occurs through the $\mathrm{NADH}$ and NADPH cofactor pyridine nucleotides, which only occur in living cells; thus, the amount of formazan formed is proportional to the number of live cells [33]. The optical density (OD) of each well was measured at $595 \mathrm{~nm}$ using a microplate reader. All tests were conducted in triplicate, and the average OD value was converted to a percentage inhibition.

\section{Results}

\section{Sample preparation and extraction}

Fresh sample $(10 \mathrm{~kg})$ was washed, cut, and dried for 7 days, which produced $953 \mathrm{~g}$ of dried samples. The dried samples were refined to produce $781 \mathrm{~g}$ of dry sample powder. Subsequently, $500 \mathrm{~g}$ of dry sample powder was extracted using methanol, which yielded $67 \mathrm{~g}$ of the methanol extract.

\section{Fractionation}

The methanol extract $(50 \mathrm{~g})$ was partitioned successively with $n$-hexane, chloroform, and n-butanol to produce the n-hexane, chloroform, and n-EB, respectively, with yields of 5.17, 3.84, and $9.27 \mathrm{~g}$, respectively. The results of the toxicity test of the three extracts are shown in Table-1. The EC was the most toxic, with an $\mathrm{LC}_{50}$ value of $39.81 \mathrm{ppm}$.

\section{Separation and purification}

The EC was separated by silica gel column chromatography using $\mathrm{n}$-hexane-chloroform $(1.5: 8.5)$ as an eluent, which produced four fractions (Fraction A, Fraction B [FB], Fraction C, and Fraction D). The toxicity data of the four fractions are shown in Table- 2 .

As shown in Table-2, the most toxic fraction was $\mathrm{FB}$, which had an $\mathrm{LC}_{50}$ value of $44.67 \mathrm{ppm}$. The FB isolate was then tested for purity using the silica gel TLC method. The tests with various eluent systems all resulted in a single stain, which indicated that the FB isolate was pure, according to TLC.

\section{Anticancer activity}

The OD data and percentage inhibition of HeLa cells after treatment with sponge $X$. testudinaria toxic isolate $(\mathrm{FB})$ are presented in Table-3.

Based on the data in Table-3, the relationship between sample concentration and inhibition was used to determine the $\mathrm{IC}_{50}$ (Figure-1).

The equation of the graph in Figure-1 is $\mathrm{y}=47.4729+8.9399 \ln (\mathrm{x})$, and the coefficient determination $\left(\mathrm{R}^{2}\right)$ was 0.9393 . Therefore, the $\mathrm{IC}_{50}$ was calculated from the following equation:

$$
\begin{gathered}
50=41.8842+9.8803 \ln (\mathrm{x}) \\
\ln (\mathrm{x})=(50-41.8842) / 9.8803=0.821412 \\
\mathrm{x}=2.273
\end{gathered}
$$

\begin{tabular}{|c|c|c|c|c|c|c|}
\hline \multirow[t]{2}{*}{ Sample } & \multirow[t]{2}{*}{ Concentration (ppm) } & \multicolumn{3}{|c|}{ Number of dead larvae } & \multirow[t]{2}{*}{ Mortality (\%) } & \multirow[t]{2}{*}{$\mathbf{L C}_{50}(\mathrm{ppm})$} \\
\hline & & $\mathbf{I}$ & II & III & & \\
\hline \multirow[t]{4}{*}{$\mathrm{EH}$} & 0 & 0 & 0 & 0 & 0 & 70.79 \\
\hline & 10 & 1 & 1 & 2 & 7 & \\
\hline & 100 & 5 & 6 & 6 & 58 & \\
\hline & 1000 & 10 & 9 & 9 & 94 & \\
\hline \multirow[t]{4}{*}{ EC } & 0 & 0 & 0 & 0 & 0 & 39.81 \\
\hline & 10 & 2 & 1 & 1 & 8 & \\
\hline & 100 & 7 & 8 & 8 & 75 & \\
\hline & 1000 & 10 & 9 & 10 & 95 & \\
\hline \multirow[t]{4}{*}{ EB } & 0 & 0 & 0 & 0 & 0 & 63.09 \\
\hline & 10 & 2 & 2 & 1 & 13 & \\
\hline & 100 & 5 & 6 & 7 & 58 & \\
\hline & 1000 & 10 & 9 & 10 & 100 & \\
\hline
\end{tabular}

Table-1: Toxicity of n-hexane, chloroform, and n-butanol extracts.

$\mathrm{EH}=$ Hexane extract, $\mathrm{EC}=$ Chloroform extract, $\mathrm{EB}=\mathrm{N}$-butanol extract 
Table-2: The toxicity of the fraction results from column chromatography.

\begin{tabular}{|c|c|c|c|c|c|c|}
\hline \multirow[t]{2}{*}{ Sample } & \multirow[t]{2}{*}{ Concentration (ppm) } & \multicolumn{3}{|c|}{ Number of dead larvae } & \multirow[t]{2}{*}{ Mortality (\%) } & \multirow[t]{2}{*}{$\mathrm{LC}_{50}(\mathrm{ppm})$} \\
\hline & & $\mathbf{I}$ & II & III & & \\
\hline \multirow[t]{4}{*}{ FA } & 0 & 0 & 0 & 0 & 0 & 50.12 \\
\hline & 10 & 2 & 1 & 1 & 7 & \\
\hline & 100 & 7 & 7 & 6 & 67 & \\
\hline & 1000 & 10 & 9 & 9 & 94 & \\
\hline \multirow[t]{4}{*}{ FB } & 0 & 0 & 0 & 0 & 0 & 44.67 \\
\hline & 10 & 2 & 1 & 1 & 8 & \\
\hline & 100 & 7 & 7 & 6 & 73 & \\
\hline & 1000 & 10 & 10 & 9 & 100 & \\
\hline \multirow[t]{4}{*}{ FC } & 0 & 0 & 0 & 0 & 0 & 56.23 \\
\hline & 10 & 2 & 2 & 1 & 13 & \\
\hline & 100 & 7 & 6 & 6 & 62 & \\
\hline & 1000 & 10 & 9 & 9 & 94 & \\
\hline \multirow[t]{4}{*}{ FD } & 0 & 0 & 0 & 0 & 0 & 79.43 \\
\hline & 10 & 2 & 2 & 1 & 13 & \\
\hline & 100 & 5 & 5 & 6 & 54 & \\
\hline & 1000 & 10 & 9 & 9 & 94 & \\
\hline
\end{tabular}

$\mathrm{FA}=$ Fraction $\mathrm{A}, \mathrm{FB}=$ Fraction $\mathrm{B}, \mathrm{FC}=$ Fraction $\mathrm{C}, \mathrm{FD}=$ Fraction $\mathrm{D}$

Table-3: Toxic isolate (FB) inhibition.

\begin{tabular}{lccccc}
\hline $\begin{array}{l}\text { Sample } \\
\text { (ppm) }\end{array}$ & \multicolumn{3}{c}{ OD } & Average & $\begin{array}{c}\text { Inhibition } \\
(\mathbf{\%})\end{array}$ \\
\cline { 2 - 4 } & $\mathbf{1}$ & $\mathbf{2}$ & $\mathbf{3}$ & & \\
\hline 100 & 0.046 & 0.045 & 0.25 & 0.038 & $80.8^{\mathrm{a}}$ \\
50 & 0.052 & 0.046 & 0.032 & 0.043 & $78.28^{\mathrm{b}}$ \\
25 & 0.062 & 0.056 & 0.03 & 0.049 & $75.25^{\mathrm{c}}$ \\
12.5 & 0.071 & 0.056 & 0.04 & 0.056 & $71.71^{\mathrm{d}}$ \\
6.25 & 0.075 & 0.063 & 0.07 & 0.069 & $65.15^{\mathrm{e}}$ \\
3.125 & 0.098 & 0.083 & 0.09 & 0.090 & $54.54^{\mathrm{f}}$ \\
1.56 & 0.102 & 0.1 & 0.1 & 0.100 & $49.49^{\mathrm{g}}$ \\
0.78 & 0.125 & 0.115 & 0.117 & 0.119 & $39.89^{\mathrm{h}}$ \\
0.39 & 0.139 & 0.140 & 0.150 & 0.143 & $27.77^{\mathrm{i}}$ \\
0.195 & 0.145 & 0.155 & 0.160 & 0.153 & $22.72^{\mathrm{j}}$ \\
Cell & 0.195 & 0.197 & 0.202 & 0.198 & $0.00^{\mathrm{k}}$ \\
control & & & & &
\end{tabular}

*Values followed by the same letters in the same column are not significantly different according to the Duncan's Multiple Range Test at $p<5 \%$. FB $=$ Fraction $B$, $\mathrm{OD}=$ Optical density

The $\mathrm{IC}_{50}$ of the toxic isolate from $\mathrm{FB}$ was $2.273 \mathrm{ppm}$, which is considered a very strong activity [34].

\section{Identification of compounds}

The GC analysis of the anticancer is presented in Figure-2. Twenty-one compounds were present in the isolate. The compounds were identified by MS and are presented in Table-4.

\section{Discussion}

The data presented in Tables-1 and 2 show that the cytotoxic potency of $X$. testudinaria sponge extract increased from the EC (39.81 ppm) to FB (44.67 ppm). This indicated that the toxic compounds in the EC exerted a synergistic effect [35]. Based on the anticancer preliminary test (toxicity test), the EC was the most toxic extract, indicating that the toxic compounds are semipolar because they dissolve into chloroform (Table-2) [36]. As shown in Figure-1, the sample concentration was positively correlated with

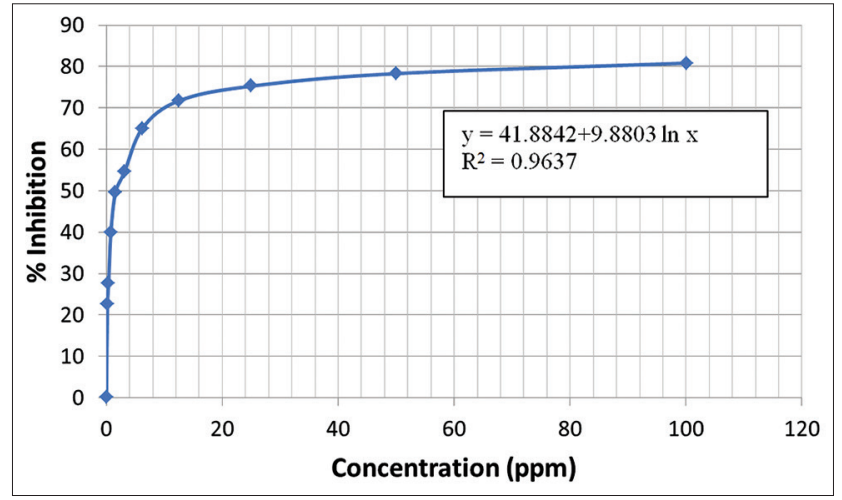

Figure-1: The curve correlation between sample concentration and inhibition.

the inhibition of HeLa cell growth. All inhibition percentages of the samples and concentrations were significantly different from the control. Compared with a previous report [19], the anticancer activity of toxic isolates was lower, with an $\mathrm{IC}_{50}$ of $2273 \mathrm{ppm}$. This showed that the anticancer compounds in the $X$. testudinaria sponge exerted synergistic effects.

The anticancer activity $\left(\mathrm{IC}_{50}=2.273 \mathrm{ppm}\right)$ of $X$. testudinaria sponge toxic isolate agreed with to a previous report [18], in which the $\mathrm{IC}_{50}$ of ethanol extract of $X$. testudinaria sponge on HeLa, HepG-2, and Daoy cells was 83.35, 23.45, and $23.31 \mathrm{ppm}$, respectively. In addition, the $\mathrm{n}-\mathrm{EH}$ from the same sponge had $\mathrm{IC}_{50}$ values of $33.7,30.2$, and $20.74 \mathrm{ppm}$ in of on HeLa, HepG-2, and Daoy cells, respectively.

We found some compounds of anticancer isolates in Table-4 were fatty acids and esters (nonanedioic acid, tetradecanoic acid, pentadecanoic acid, palmitic acid, docosanoic acid, ethyl ester, 9,12-octadecadienoic acid, phosphonic acid, and dioctadecyl ester). The derivatives of phenyl oleic acid are known to inhibit the growth of MCF-7 and HT-29 cancer cells, with $\mathrm{IC}_{50}$ values of $48 \mathrm{ppm}$, whereas n-butyl oleic acid derivatives inhibited the growth of these cells with $\mathrm{IC}_{50}$ 


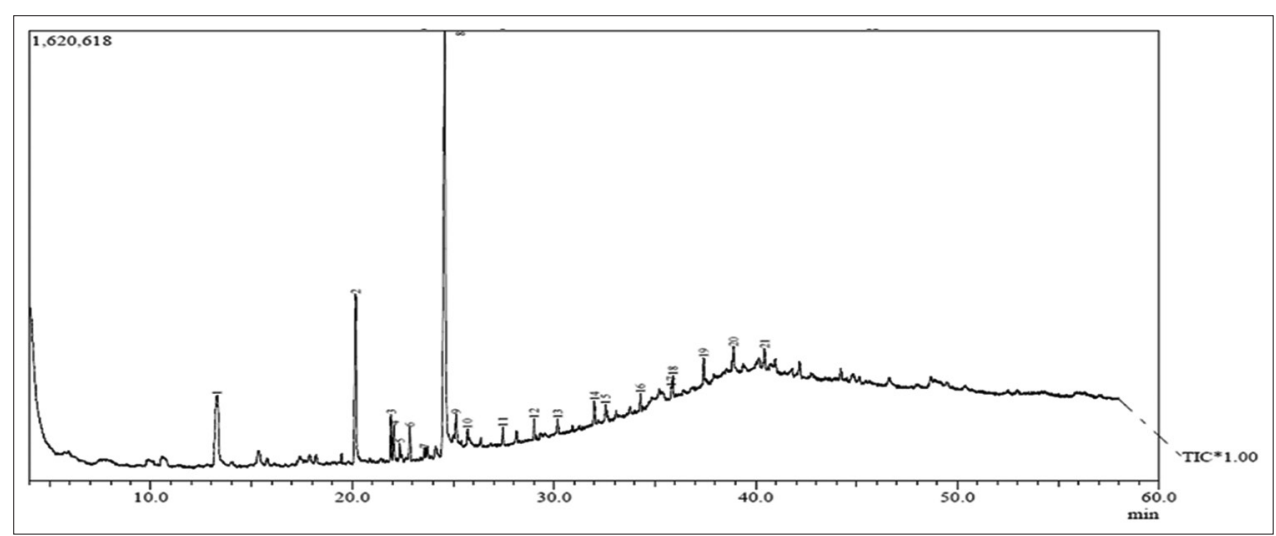

Figure-2: Gas chromatogram of the anticancer isolate of Xestospongia testudinaria sponge.

Table-4: Compounds identified in the anticancer isolate of $X$. testudinaria sponge.

\begin{tabular}{lcccll}
\hline Peak & $\begin{array}{c}\text { Retention } \\
\text { time (min) }\end{array}$ & Abundance (\%) & $\begin{array}{c}\text { Molecular } \\
\text { weight }\end{array}$ & $\begin{array}{c}\text { Molecular } \\
\text { formula }\end{array}$ & Compound name \\
\hline 1 & 13.283 & 13.66 & 188 & $\mathrm{C}_{9} \mathrm{H}_{16} \mathrm{O} \mathrm{O}$ & Nonanedioic acid \\
2 & 20.167 & 15.37 & 228 & $\mathrm{C}_{14} \mathrm{H}_{28} \mathrm{O}_{2}$ & Tetradecanoic acid \\
3 & 21.917 & 2.77 & 296 & $\mathrm{C}_{20} \mathrm{H}_{40} \mathrm{O}$ & Trans-phytol \\
4 & 22.067 & 2.22 & 268 & $\mathrm{C}_{18} \mathrm{H}_{36} \mathrm{O}$ & 2-Pentadecanone-6,10,14-trimethyl \\
5 & 22.350 & 0.99 & 242 & $\mathrm{C}_{15} \mathrm{H}_{30} \mathrm{O}_{2}$ & Pentadecanoic acid \\
6 & 22.850 & 2.02 & 278 & $\mathrm{C}_{20} \mathrm{H}_{38}$ & 2-Hexadecen-1-ol, 3,7,11,15-tetramethyl- \\
7 & 23.575 & 0.43 & 170 & $\mathrm{C}_{11} \mathrm{H}_{22} \mathrm{O}$ & 2,3,7-Trimethyloctanal \\
8 & 24.583 & 50.24 & 256 & $\mathrm{C} 16_{32} \mathrm{H}_{32} \mathrm{O}_{2}$ & Palmitic acid \\
9 & 25.150 & 1.50 & 368 & $\mathrm{C}_{24} \mathrm{H}_{48} \mathrm{O}_{2}$ & Docosanoic acid, ethyl ester \\
10 & 25.717 & 0.75 & 248 & $\mathrm{C}_{18} \mathrm{H}_{32}$ & 1, E-11, Z-13-octadecatriene \\
11 & 27.458 & 0.88 & 282 & $\mathrm{C}_{13} \mathrm{H}_{24} \mathrm{Cl}_{2} \mathrm{O}_{2}$ & Chloromethyl 4-chlorododecanoate \\
12 & 29.017 & 1.04 & 322 & $\mathrm{C}_{23} \mathrm{H}_{46}$ & 1-Tricosene \\
13 & 30.183 & 0.48 & 294 & $\mathrm{C}_{19} \mathrm{H}_{34} \mathrm{O}_{2}$ & 9,12-Octadecadienoic acid \\
14 & 32.000 & 1.39 & 324 & $\mathrm{C}_{21} \mathrm{H}_{40} \mathrm{O}_{2}$ & 4,8,12,16-Tetramethylheptadecan-4-olide \\
15 & 32.550 & 0.57 & 308 & $\mathrm{C}_{22} \mathrm{H}_{44}$ & 1-Docosene \\
16 & 34.292 & 0.72 & 296 & $\mathrm{C}_{21} \mathrm{H}_{44}$ & Heneicosane \\
17 & 35.817 & 0.69 & 586 & $\mathrm{C}_{36} \mathrm{H}_{75} \mathrm{O}_{3} \mathrm{P}$ & Phosphonic acid, dioctadecyl ester \\
18 & 35.892 & 1.12 & $\mathrm{C}_{14} \mathrm{H}_{30}$ & Dodecane, 4,6-dimethyl- \\
19 & 37.417 & 1.52 & $\mathrm{C}_{34} \mathrm{H}_{70}$ & n-Tetratriacontane \\
20 & 38.900 & 0.87 & 378 & $\mathrm{C}_{16} \mathrm{H}_{33} \mathrm{I}$ & 1-Iodohexadecane \\
21 & 40.450 & 0.79 & 296 & $\mathrm{C}_{21} \mathrm{H}_{44}$ & n-Heneicosane \\
\hline
\end{tabular}

X. testudinaria $=$ Xestospongia testudinaria

values of $82 \mathrm{ppm}$ and $77 \mathrm{ppm}$, respectively [37]. The anticancer activity of $\omega-6$ polyunsaturated fatty acids is known [38]. Compounds isolated from Cladophora fracta, such as oleic acid, palmitic acid, gamma-linolenic acid, and linoleic acid, are reported to have strong antiproliferative activity [39]. Anticancer properties are also found in palmitic acid, (Z)-9-octadecenoic acid, and octadecenoic acid isolated from Protaetia brevitarsis larvae [40].

Terpenoid compounds were also detected in anticancer isolates from $X$. testudinaria sponge; namely, trans phytol, 1-tricosene, and 2-hexadecen-1-ol, 3,7,11,15-tetramethyl-. These results were in accordance with previous publications, which reported that phytol and diterpene alcohol compounds had anticancer activities in MCF-7 and PC-3 cells, with $\mathrm{IC}_{50}$ values of $8.79 \pm 0.41 \mu \mathrm{M}$ and $77.85 \pm 1.93 \mu \mathrm{M}$, respectively [41]. Other phytol and diterpenes were isolated from Justicia gendarussa Burm. f. used as an anti-inflammatory, with histamine release (26.92\%), serotine and bradykinin (49.90\%), and prostaglandin (68.03\%) as compared with the standard (Diclofenac $5 \mathrm{mg} / \mathrm{kg}$ ) [42]. Phytol also shows anti-angiogenic activity and induces apoptosis in A549 cells by depolarizing the mitochondrial membrane $[43,44]$.

Hydrocarbons (4,8,12,16-tetramethylheptadecan-4-olide; 1-docosene; heneicosane; n-heneicosane) were detected in the anticancer isolate of $X$. testudinaria sponge. Pyrenyl ether, which is a polycyclic aromatic compound with a good cytotoxic effect against cisplatin-induced colon cancer cells (HT-29) and HeLa cancer cells [45]. Essential oil from Gannan navel orange peel, which contains linalool, 3-carene, $\alpha$-terpineol, decanal, citral, D-limonene, and $\alpha$-pinene, is reported to have anticancer activity against Hela cells [46]. The sterol fraction of Taonia atomaria can inhibit cancer cells: HePG2, A549, HCT116, and MCF7 [47]. The antitumor activity of saturated aliphatic hydrocarbons in Pyrostegia venusta, namely, octasane and triacontane compounds from the heptane extract, has also been reported [48]. 


\section{Conclusion}

The anticancer activity of $X$. testudinaria sponge toxic isolates was positively correlated with the inhibition of HeLa cell growth, with an $\mathrm{IC}_{50}$ of $2.273 \mathrm{ppm}$. In total, 21 compounds were identified in toxic isolate; three groups of compounds were identified, namely, fatty acids and esters, terpenoids, and hydrocarbons.

\section{Authors' Contributions}

MDS designed and conducted the experiment, acquisition of data, and drafting of the manuscript. WSR conducted the experiment and collected the data. NS designed the experiment, drafting of the manuscript. KKA analyzed the data and drafting the manuscript. All authors read and approved the final manuscript.

\section{Acknowledgments}

The authors wish to express their gratitude to the Directorate of Research and Community Service, Directorate-General for Research and Development, Ministry of Research, Technology and Higher Education of the Republic of Indonesia that have funded this research through National strategic research Institution Grant Year 2018 with Contract No. 171.85/UN14.4.A/LT/2018. The authors would also like to thank the Institute for Research and Community Services, Udayana University, which has been facilitated this research.

\section{Competing Interests} interests.

The authors declare that they have no competing

\section{Publisher's Note}

Veterinary World remains neutral with regard to jurisdictional claims in published institutional affiliation.

\section{References}

1. Hejmadi, M. (2010) Introduction to Cancer Biology. $2^{\text {nd }}$ ed. Bookboon, Denmark

2. Martin, T.A., Ye, L., Sanders, A.J., Lane, J. and Jiang, W.G. (2013) Cancer Invasion and Metastasis: Molecular and Cellular Perspective. Landes Biosci, Austin. p1-34.

3. Zaorsky, N.G., Churilla, T.M., Egleston, B.L., Fisher, S.G., Ridge, J.A., Horwitz, E.M. and Meyer, J.E. (2017) Causes of death among cancer patients. Ann. Oncol., 28(2): 400-407.

4. World Health Organization. (2018) Cancer, Fact Sheets. Available from: http://www.who.int/news-room/factsheets/detail/cancer. Last accessed on 31-03-2019.

5. Chakraborty, S. and Rahman, T. (2012) The difficulties in cancer treatment. Ecancermedicalscience, 6(16): 1-5.

6. World Health Organization. (2013) Human Papilloma Virus (HPV) and Cervical Cancer. Available from: http://www. who.int/mediacentre/factsheets/fs380/en. Last accessed on 31-03-2019.

7. Edianto, D. (2006) Cervical Cancer. Bina Pustaka Foundation Sarwono Prawirahardjo, Jakarta.

8. Abeloff, M., Arnitage, J., Niederhuber, J., Kastan, M. and McKenna, W. (2004) Clinical Oncology. $3^{\text {rd }}$ ed. Elsevier Churchill Livingstone, Philadelphia, PA.

9. Maeda, H. and Khatami, M. (2018) Analyses of repeated failures in cancer therapy for solid tumors: Poor tumor-selective drug delivery, low therapeutic efficacy and unsustainable costs. Clin. Transl. Med., 7(11): 1-20.

10. Boopathy, S.N. and Kathiresan, K. (2010) Anticancer drugs from marine flora: An overview. J. Oncol., 2010(214186): $1-18$

11. Trianto, A., Ambariyanto, and Murwani, R. (2004) Skrining bahan anti kanker pada berbagai jenis sponge dan gorgonian terhadap L1210 cell line. Ilmu Kelautan, 9(3): 120-124.

12. Munro, M.H.G., Luibrand, R.T. and Blunt, J.W. (1989) The search for antiviral and anticancer compounds from marine organisms. Bioorganic. Med. Chem., 1(1): 94-176.

13. Soediro, I.S. (1999) Marine Biological Products and Prospects for Utilization in Health and Cosmetics. Proceeding Indonesian Marine Biotechnology Seminar I. Jakarta. p41-52.

14. Soest, R.W.M. and Braekman, J.C. (1999)Chemosystematics of porifera: A review. Mem. Qld. Mus., 44(1-2): 569-589.

15. Hassan, W.H.B. (2004) Isolation and Structure Elucidation of Bioactive Secondary Metabolites from Marine Sponges. Thesis Dissertation Heinrich Heine, Düsseldorf.

16. Hanani, E., Mun'im, A. and Sekarini, R. (2005) Identifikasi senyawa antioksidan dalam spons Callyspongia spp. dari kepulauan seribu. Majalah Ilmu Kefarmasian, 2(3): 127-133

17. Kobayashi, M. and Rachmaniar, R. (1999) Overview of Marine Natural Product Chemistry. Proceeding Indonesian Marine Biotechnology Seminar I. Jakarta. p23-32.

18. El-Gamal, A.A., Al-Massarani, S.M., Shaala, L.A., Alahdald, A.M., Al-Said, M.S., Ashour, A.E., Kumar, A., Abdel-Kader, M.S., Abdel-Mageed, W.M. and Youssef, D.T. (2016) Cytotoxic compounds from the Saudi red sea sponge Xestospongia testudinaria. Mar. Drugs, 14(5): 1-9.

19. Swantara, I.M.D., Rita, W.S. and Suartha, I.N. (2018) Anticancer activities of toxic extract of Xestospongia testudinaria sponge from Sanur Beach, Bali, Indonesia. Res. J. Pharm. Biol. Chem. Sci., 9(3): 1036-1041.

20. Ayyad, S.E.N., Katoua, D.F., Alarif, W.M., Sobahi, T.R., Aly, M.M., Shaala, L.A. and Ghandourah, M.A. (2015) Two new polyacetylene derivatives from the red sea sponge Xestospongia spp. Z. Naturforsch. C, 70(11-12): 297-303.

21. Bourguet-Kondracki, M.L., Rakotoarisoa, M.T., Martin, M.T. and Guyot, M. (1992) Bioactive bromopolyacetylenes from the marine sponge Xestospongia testudinaria. Tetrahedron Lett., 33(2): 225-226.

22. Cita, Y.P., Suhermanto, A., Radjasa, O.K. and Sudharmono, P. (2017) Antibacterial activity of marine bacteria isolated from sponge Xestospongia testudinaria from Sorong, Papua. Asian Pac. J. Trop. Biomed., 7(5): 450-454.

23. Nguyen, X.C., Longeon, A., Pham, V.C., Urvois, F., Bressy, C., Trinh, T.T.V., Nguyen, H.N., Phan, V.K., Chau, V.M., Briand, J.F. and Bourguet-Kondracki, M.L. (2013) Antifouling 26, 27-cyclosterols from the Vietnamese marine sponge Xestospongia testudinaria. J. Nat. Prod., 76(7): 1313-1318.

24. Zhou, C., Yuan, K., Tang, X., Hu, N. and Peng, W. (2011) Molecular genetic evidence for polyandry in Ascaris suum. Parasitol. Res., 108(3): 703-708.

25. Swantara, I.M.D. and Rita, W.S. (2018) Toxicity of sponge extract Xestospongia testudinaria. Int. J. Eng. Sci. Invent., 7(5): 55-58.

26. Meyer, B.N., Ferrigni, N.R., Putnam, J.E., Jacobsen, L.B., Nicholas, D.E. and Mclaughlin, J.L. (1982) Birne shrimp: A convenient general bioassay for active plant constituents. J. Med. Plant Res., 45(1): 31-34.

27. Ekowati, H., Astuti, I. and Mustofa, M. (2010) Anticancer activity of calanone on HeLa cell line. Indones. J. Chem., 10(2): 247-251.

28. Carballo, J.L., Hernández-Inda, Z.L., Pérez, P. and GarcíaGrávalos, M.D. (2002) A comparison between two brine shrimp assays to detect in vitro cytotoxicity in marine natural products. BMC Biotechnol., 2(17): 1-5. 
29. McCauley, J., Zivanovic, A. and Skropeta, D. (2013) Bioassays for anticancer activities. Methods Mol. Biol., 1055(1): 191-205.

30. Byju, K., Anuradha, V., Vasundhara, G., Nair, S.M. and Kumar, C.N. (2014) In vitro and in silico studies on the anticancer and apoptosis-inducing activities of the sterols identified from the soft coral, Subergorgia reticulata. Pharmacogn. Mag., 10(Suppl 1): S65-S71.

31. Ganesh, M. and Mohankumar, M. (2017) Extraction and identification of bioactive components in Sida cordata (Burm.f.) using gas chromatography-mass spectrometry. $J$. Food Sci. Technol., 54(10): 3082-3091.

32. Mosmann, T. (1983) Rapid colorimetric assay for cellular growth and survival: Application to proliferation and cytotoxicity assays. J. Immunol. Methods, 65(1-2): 55-63.

33. Doyle, A. and Griffiths, J.B. (2000) Cell and Tissue Culture for Medical Research. New York: John Wiley and Sons Ltd.

34. Chao, S.G., Valerie, H.L., Wu, X.H., Sim, K.Y., Tan, B.H.K. and Pereira, J.T. (1998) Novel cytotoxic olyprenylated xanthones from Garcinia gaudichaudii. Tetrahedron, 54(36): 10915-10924.

35. Machana, S., Weerapreeyakul, N., Barusrux, S., Thumanu, K. and Tanthanuch, W. (2012) Synergistic anticancer effect of the extracts from Polyalthia evecta caused apoptosis in human hepatoma (HepG2) cells. Asian Pac. J. Trop. Biomed., 2(8): 589-596.

36. Rakhmawati, R., Anggarwulan, E. and Retnaningtyas, E. (2009) Potency of lobak leaves (Raphanus sativus L. var. Hortensis back) as anticancer and antimicrobial candidates. Biodiversitas, 10(3): 158-162.

37. Dailey, O.D.J., Wang, X., Chen, F. and Huang, G. (2011) Anticancer activity of branched-chain derivatives of oleic acid. Anticancer Res., 31(10): 3165-3169.

38. Xu, Y. and Qian, S.Y. (2014) Anti-cancer activities of $\omega-6$ polyunsaturated fatty acids. Biomed. J., 37(3): 112-119.

39. Karan, T. and Erenler, R. (2018) Fatty acid constituents and anticancer activity of Cladophora fracta (OF Müller ex Vahl) kützing. Trop. J. Pharm. Res., 17(10): 1977-1982.
40. Yoo, Y.C., Shin, B.H., Hong, J.H., Lee, J., Chee, H.Y., Song, K.S. and Lee, K.B. (2007) Isolation of fatty acids with anticancer activity from Protaetia brevitarsis larva. Arch. Pharm. Res., 30(3): 361-365.

41. Pejin, B., Kojic, V. and Bogdanovic, G. (2014) An insight into the cytotoxic activity of phytol at in vitro conditions. Nat. Prod. Res., 28(22): 2053-2056.

42. Phatangare, N.D., Deshmukh, K.K., Murade, V.D., Hase, G.J. and Gaje, T.R. (2017) Isolation and characterization of phytol from Justicia gendarussa Burm. f. An anti-inflammatory compound. Int. J. Pharmacogn. Phytochem. Res., 9(6): 864-872.

43. Jeong, S.H. (2018) Inhibitory effect of phytol on cellular senescence. Biomed. Dermatol., 2(13): 1-9.

44. Sakthivel, R., Malar, D.S. and Devi, K.P. (2018) Phytol shows anti-angiogenic activity and induces apoptosis in A549 cells by depolarizing the mitochondrial membrane potential. Biomed. Pharmacother., 105(2018): 742-752.

45. Bandyopadhyay, D., Granados, J.C., Short, J.D. and Banik, B.K. (2012) Polycyclic aromatic compounds as anticancer agents: Evaluation of synthesis and in vitro cytotoxicity. Oncol. Lett., 3(1): 45-49.

46. Yang, C., Chen, H., Chen, H., Zhong, B., Luo, X. and Chun, J. (2017) Antioxidant and anticancer activities of essential oil from gannan navel orange peel. Molecules, 22(1391): 1-10.

47. Ibrahim, E.A., Aly, H.F., Baker, D.H.A., Mahmoud, K. and El-Baz, F.K. (2016) Marine algal sterol hydrocarbon with anti-inflammatory, anticancer and antioxidant properties. Int. J. Pharm. Bio. Sci., 7(3): 392-398.

48. Figueiredo, C.R., Matsuo, A.L., Pereira, F.V., Rabaca, A.N., Farias, C.F., Girola, N., Massaoka, M.H., Azevedo, R.A., Scutti, J.A., Arruda, D.C., Silva, L.P., Rodrigues, E.G., Lago, J.H., Travassos, L.R. and Silva, R.M. (2014) Pyrostegia venusta heptane extract containing saturated aliphatic hydrocarbons induces apoptosis on B16F10-Nex2 melanoma cells and displays antitumor activity in vivo. Pharmacogn. Mag., 10(38): S363.

\section{$* * * * * * * *$}

